\title{
Critique of ISIS' Women Policy
}

\author{
Zehra Y1lmaz*
}

\begin{abstract}
This article addresses the policy employed by ISIS with respect to women. ISIS differs from other extremist organisations in terms of its impact on women and specifically, the number of female militants it has recruited from the West. Such high numbers of women joining ISIS is striking when considered in the face of the fact that ISIS is well known to be involved in rather oppressive and barbaric practices in territories under its control. Therefore, the article examined the reasons that trigger women to join ISIS and the promises of ISIS for women. The present review builds the policy employed by ISIS with respect to women upon the meanings attributed to women in the founding process of a state and the manner in which women experience this process. Focused on the policy employed by ISIS with respect to women, the article carries on the claim of extending beyond a cultural discourse inflicted with orientalist prejudices by addressing the matter from the perspective of the state and its gender perspective in contrary to research studies approaching ISIS and women from a theological standpoint.
\end{abstract}

Keywords: ISIS, Women, Manifesto, State Building Process, Islam

PhD. Asst. Prof., Van Yuzuncu Y1l University, Department of International Relations, zehra80@yahoo.com 


\title{
DAEŞ'in Kadın Politikasının Eleștirisi
}

\author{
Zehra Y1lmaz*
}

\section{Öz}

Bu makalede DAEŞ'in kadın politikası ele alınmaktadır. DAEŞ, kadınlarda yarattığı etkiyle, özellikle batıdan edindiği kadın militan sayısıyla diğer radikal örgütlerden farklılaşmaktadır. DAEŞ'in kontrol ettiği topraklarda oldukça baskıcı ve barbar uygulamalarda bulunduğu bilinmesine rağmen kadınların DAEŞ'e bu yoğunlukta katılımı dikkat çekmektedir. Bu nedenle, makalede kadınları DAEŞ'e katılmaya iten gerekçelerle DAEŞ'in kadınlara vaat ettikleri karşılaştırılmalı incelenmiştir. Bu incelemede, DAEŞ'in kadın politikası devlet kurma sürecinde kadına yüklenen anlamlar ve kadınların bu süreci deneyimleme biçimi üzerine inşa edilmiştir. DAEŞ'in kadın politikasını açıklamaya odaklanan makale, DAEŞ ve kadın söz konusu olduğunda konuya teolojik olarak yaklaşan araştırmaların tersine, konuyu devlet ve onun toplumsal cinsiyet perspektifi üzerinden ele alarak oryantalist önyargılar taşıyan kültürcü bir söylemin ötesine geçme iddiası taşımaktadir.

Anahtar Kelimeler: DAEŞ, Kadın, Manifesto, Devlet Kurma Süreci, İslam

* Yrd. Doç. Dr., Van Yüzüncü Yıl Üniversitesi, Uluslararası İlişkiler Bölümü, zehra80@yahoo.com 


\section{Introduction}

We have only little information on the policy on women employed by ISIS (Islamic State of Iraq and al-Sham) since the number of women who have been separated from ISIS is rather low when compared to that of male ISIS militants. Therefore, our information regarding the policy on women employed by ISIS is based upon two matters in the current situation. The first matter is represented by the systematic rape of and other forms of sexual violence against Yezidi women by ISIS militants, while the second concerns specifically the participation of European women in ISIS. In fact, both arguments are discussed from a very orientalist perspective. Although the systematic crimes committed by Serbians against Muslim women in the Bosnian War including rape and sexual assault are still fresh in the minds, rapes against Yezidi women are addressed only through the argument that "ISIS is serving us on the basis of the Religion of Islam". On the other hand, the case of 'European women joining ISIS' has been argued through a dichotomy structured with mentions of how women leave the 'modern' and 'progressive' West and prefer to live under "tyrannical" and "counter-progressive" domination with ISIS. If we do not think that ISIS has convinced women by using "kittens" and "Nutella" photos on Twitter like CNN's Newsroom anchor claims, we should rethink ISIS' policy on women beyond the orientalist perspective. In fact, the opposite site of this perspective does not provide any meaning other than repeating the common discourse that emphasizes the fact that "ISIS is a barbaric organization placing strain on women".

This article will analyse ISIS's policy on women and will try to move this discussion beyond the orientalist perspective. In that case, we should not analyse ISIS's policy on women in the cultural frame, because, this issue is related with patriarchy in the state-building process rather than Islam or any other "cultural matter". At that point, first of all, I will try to understand if there is discrimination and domination on the grounds of sex in areas controlled by ISIS and why women tend to consent to their slavery. For this reason, in this article, I mainly tried to analyse the policy employed by ISIS on women through the Manifesto published by ISIS

See the discussion about the ISIS' slavery policy in "The Revival of Slavery: Before the Hour", Dabiq, 2015. 
with the heading of "Women of the Islamic State: A Manifesto on Women by the Al-Khanssaa Brigade". I built my analyses -on the women policy of ISIS- upon the Manifesto. I assessed the effects of the life -envisaged for women in the Manifesto- on ISIS' recruitment of women. In this context, I tried to explain that the dream of establishing a "Shariah state" is a utopia motivating women as well as men. But while explaining the motivational components, I state that women are utilised in a different manner than men in the founding process of a state. Along with emphasizing the common grounds for women and men in reaching that utopia by considering the different utilisation of genders, I also referred to the structural reasons for the imposition on women to join ISIS. For examples while women join ISIS from Western countries because they feel that they are culturally excluded, on the other hand, women join ISIS from the Middle East because they see ISIS as a protector for them in the insecure conditions of war. In the frame of these notions, I finally included in the assessment the cultural bias in the background pertaining to the distinction of "Western" and "Eastern" among women joining ISIS.

\section{Fundamentals of ISIS' Gender Policy}

In order to understand ISIS' policy on women, we need to consider the Manifesto published by ISIS. The Manifesto was published in Arabic with the title "Women of the Islamic State: A Manifesto on Women by the AlKhanssaa Brigade" on $25^{\text {th }}$ January, 2015. As can be gathered from its title, the Manifesto was written by Al-Khanssaa, a brigade under ISIS composed only of women themselves. Arguing that the Manifesto was written by female militants, ISIS seems to create an image where women have a say on matters concerning their lives in the territories under its control. However, a heated debate is on-going on the extent to which this image is reflected on women's lives by ISIS. In fact, it is almost impossible even to collect relevant information once one goes past the territories under ISIS' control.

Another matter of importance is the language employed in the Manifesto. Written in Arabic, the Manifesto is then translated into English by Charlie Winter, a researcher on Jihadism and Syria and Iraq at the counter-extremism think-tank, the Quilliam Foundation. The fact that the Manifesto was written 
in Arabic is significant in that it indicates that ISIS primarily targets Arabic women or at least women who can speak Arabic with this text. Indeed, a chapter in the Manifesto is addressed to Saudi Arabia, a Muslim country, by reason of its policy on women. The Manifesto alleges that women in Saudi Arabia are living under 'barbarism and savagery'. Therefore, these women are recommended to migrate to the territories under the control of ISIS. Prominent criticisms specified in the Manifesto evidently concern how Westernisation and female states generated by Westernisation threaten 'the Islamic lifestyle' of women. However, ISIS positions itself above other interpretations of Islam and other Islamic administrations claiming that it represents "true Islam" and defines other Islamic interpretations and administrations as a threat to itself on the secondary level, even though the primary target of the criticisms expressed in the Manifesto is the West. It also extends criticisms towards such interpretations and administrations. The call for women living in Saudi Arabia to the territories under ISIS' control is also an extension of this understanding. According to this call, if ISIS recommends and enables all to experience the truest Islam, then Arabic women can only realise their Islam in the best manner possible under ISIS administration.

Nevertheless, Winter, who translated the text into English, points out to the fact that there are militants in ISIS who have a good command of the English language and assesses the publication of the Manifesto by ISIS in Arabic and not in English in this context as a manoeuvre directly addressing Muslims living in the West. He explains his argument with the following statements in an interview with The Independence.

The document will be exaggerated and not a completely accurate reflection of what life is like, but what it does give us is a conceptual treatise of what life should be like and that's something that we haven't seen yet, at least not in English. Somebody will have made a decision not to circulate a manifesto like this in English because it contains uncomfortable ideas that may not sit well with the average Western girl looking to join the group. ${ }^{2}$

Certain studies confirm Winter's assessment. According to these studies, the knowledge about Islam of ISIS militants is rather insufficient when

Heather Saul , "Life as Woman Under ISIS Document Reveals for the First Time What Group Really Expects from Female Recruits Living in Syria and Iraq", Independent, 2015, July 23. 
compared to the other Jihadist organisations. In fact, it is alleged that body searches of certain militants joining ISIS resulted in such elementary books as Islam for Beginners ${ }^{3}$. Thus, we can approve Charlie Winter's argument with respect to the use of Arabic only for the writing of the Manifesto at this point and state that ISIS might have wanted to exploit the ignorance of those living in the West with respect to the Religion of Islam going beyond targeting Arabic women and women with a good command on the Arabic language by publishing the Manifesto in Arabic.

However, there is another point to be taken into consideration in the analysis of this matter. When it comes to women, ISIS is comfortable with addressing their lifestyle in territories under ISIS administration with texts published in both English and Arabic. As an example, the article entitled The Revival of Slavery Before the Hour in Dabiq, published as the media organ of ISIS in English and Arabic, explains in detail and defends the use of Yezidi women as slaves ${ }^{4}$. Express statements condoning the use of nonMuslim women as slaves establish the fact that ISIS is not concerned at all with concealing itself.

In fact, the addressing of Muslim women and non-Muslim women in different texts show us that the policy employed by ISIS with respect to women is based upon a certain hierarchy established among women. ISIS divides women into two: Muslim women and non-Muslim women. As mentioned in the Manifesto which I analysed, Muslim women are defined as those whom Muslim men can marry and have children with, whereas non-Muslim women are given an inferior status to Muslim women as women who can be raped and used as slaves. Therefore, women defined in these two categories are addressed and specified separately and mostly in different texts.

In this framework, the Manifesto, identifying the fundamentals of how Muslim women live under ISIS administration, cites the preamble for the text as primarily "To clarify the role of Muslim women and the life which is desired for them, that which will make them happy in this world and

Ümit Kıvanç, “işi̇D-DAİş’e Batı'dan Niye Katılıyorlar?” Radikal Gazetesi, 2015, October 11 .

$4 \quad$ “The Revival of Slavery: Before the Hour", Dabiq, 2015. 
the hereafter"s. Secondary and tertiary justifications for the writing of the Manifesto focus on the traces of the said promise of "happiness' in "real" life: "To clarify the realities of life and the hallowed existence of women in the Islamic State, in Iraq and in al-Sham, and to refute the rumours that detractors advance against it, using evidence supported and experienced by women living there. And to expose the falsity of the tawheed in the Arabian Peninsula, which claims to be unique in protecting the women and preserving her rights and religion. If you ask any Muslim, male or female, on the reason for the choice of this country as a comparison with the Islamic State, I say, thanks be to God the highest"

Considering this order of justifications, the publication of a Manifesto only targeting women by ISIS in its process of founding an Islamic state reminds us of the statements of Feminist thinker Nira Yuval-Davis. As Yuval-Davis says, "... membership of women to national and ethnic communities is double-edged. On one hand, women are members of the community just like men. On the other hand, there are special rules and regulations only concerning their existence as women"7. This Manifesto published by ISIS naturally confirms the analysis undertaken by Yuval-Davis considering not only Muslim communities, but also different nationalisation processes. Indeed, its content only covers regulations pertaining to women.

Nevertheless, the manner in which the role of women in the state founded under ISIS administration is defined differs from that of conventional nationstate configuration. In fact, women are not considered to be dependent on a certain territory within ISIS; ISIS, on the contrary, mobilises women so that they can remain wherever Jihad is. A woman is defined not as a part of a specific territory, state or nation, but as a part of the Muslim community. In this framework, women are restricted not by the nation, but within the family. The family is, in turn, shaped through women and their fertility as a micro particle that ties the Muslim community together as an expression of a large-scale unity of Muslims. Accordingly, the Manifesto builds the roles of women in societal terms and places manhood opposite womanhood. In addition, the roles of men and women can never intersect.

Charlie Winter, "Women of the Islamic State: A Manifesto on Women by the AlKhanssaa Brigade", Quilliam, February 2015.

Ibid., p. 12.

Nira Yuval Davis and Floya Anthias, Woman-Nation State, London, Macmillan, 1989. 
On the other hand, it is rather striking to observe the assumptions that the lifestyle recommended by the Manifesto will bring happiness to women, i.e. the presupposition that women are looking for happiness in the first place, in the order of justifications for the Manifesto. This 'pleasure'based method of propaganda is used by ISIS for both women and men in various forms. While the 'pleasure' is limited with their contributions to the existence of the Islamic state for women, the search of men for 'pleasure' is generally addressed on the basis of sexuality and, in fact, mostly pornographic sexuality. The promise of female slaves to male recruits is the reflection of such a pleasure-oriented approach. In fact, the publication and dissemination of images of rape against Yezidi women by men of ISIS is some reflection of the unification of sexual violence of men against women with a pornographic representation. This pleasureoriented approach that feeds into rape as a strategy of war is regarded also as a notion that complements the image of "real men" mentioned in the Manifesto and attributed to ISIS militants.

In this sense, the expression of "real men" emphasised in the Manifesto is of great importance in order for us to understand the sense of manhood employed by ISIS. In fact, sexual assault and rape against women employed frequently by ISIS during war assumes a functional meaning in the face of the aforementioned notion of manhood. As an example, the sexual assault and rape against approximately 3000 women and children kidnapped and kept captive by ISIS were imprinted upon everyone's minds so to say when combined with the images serviced by ISIS $^{8}$. The report prepared by Human Rights Watch on the basis of its interviews with female victims of sexual assault and rape by ISIS militants demonstrates, in the clearest way possible, the severe sexual violence exerted by ISIS militants against women sold at markets9. ISIS puts forth Islam to give the appearance of legitimacy to such sexual assault and rape. However, the use of rape as a strategy of war is a method also backed by such an old history that it cannot be connected with Islam and employed by communities of different religions. For instance, "the most common pattern in warfare in the ancient

\footnotetext{
"Roughly 3000 Women and Girls are Sold on ISIS Sex Slave market Using Telegram, Whatsapp”, Ny Daily News, July 6, 2016.

9 Rothna Begum and Samer Muscati, "Interview: These Yezidi Girls Escaped ISIS. Now What?", Human Rights Watch, April 15, 2015.
} 
Middle East and Greece was to literally feminize a conquered population by executing male captives, raping the women then taking women and children as slaves" ${ }^{10}$. Therefore, the matter seems to be connected more with manhood than religion. In a more plain language, we need to consider the promise of female slaves as a method used by ISIS to recruit new members or the rape of non-Muslim women in wars in the context not of Islam, but of the image of 'real men' created by ISIS.

Even though rape has been used as a common strategy of war by different states and organisations before, the strategy utilised by ISIS is different from the previous examples in one sense. The rape and enslavement of Yezidi women is not only a strategy of war, but also a means of recruiting militants on the global scale for ISIS. Thus, Muslim women are upheld as raisers of children for Jihad, while the myth of "rapeable women" used for non-Muslim women indicates both the denigration of non-Muslim women and the goal of recruiting mujahids on the global scale in the hierarchy established by ISIS among women. The online dissemination of images concerning the rape of non-Muslim women is also a part of this strategy of denigration. We observe the embodiment of a "revenge" psychology whereby one tries to denigrate others with the same severity to rid themselves of their own sense of being denigrated. Therefore, the systematic rapes committed by ISIS militants in areas under their occupation should be considered as a part of the revanchist attitude towards the understanding of "defeated Islam". ISIS militants wreak their grudge against any enemies that defeated Islam and may hinder Jihadism upon women by raping them or upon men by beheading them. It is obvious that this attitude appears to be politically irrational, but it certainly creates an ideological point of attraction for ISIS.

In fact, the rape or sexual violence of ISIS against female enemies is being legitimised on the basis of the grudge experienced by women under ISIS through their past experiences being counteracted by men of ISIS. Because, as the reports mentioned rape, used as a strategy of war, was also employed by the troops of Bashar al Assad against prisoners. For example, the report published by Human Rights Watch with the title Arbitrary Arrests, Torture

10 Joshua S. Goldstein, War and Gender: How Gender Shapes the War System and Vice Versa, Cambridge: Cambridge University Press, 2001. 
and Enforced Disappearance Syria's Underground Prisons Since March 2011 states that men, women and children were made subject to a number of torture methods including sexual violence, rape, electric shock, acid burn, denailing or forced and long tensile positioning by Syrian government forces in prisons in Damascus, Aleppo, Homs, Dera and Latakia ${ }^{11}$.

In this case, for the ISIS it seems that the psychology of revenge also exacerbates the dimensions of violence. McCants explains this psychology of grudge that feeds ISIS as follows: "They believed that ISIS women had been raped by other Sunni rebels, so they framed their whole counteroffensive against other Sunni rebels as a retribution for this"12. Therefore, since women perceive themselves to be threatened specifically at times of war, "the region controlled by ISIS is seen as a "safe-haven for those who wish to follow Islam in its entirety or those who wish to live by Tawheed"13. The situation of women who are looking for a 'safe shelter' for themselves in this conflict between rapist men clearly and primarily demonstrates the masculine dimension of the war. Nevertheless, the asylum of the aforementioned women to find shelter for themselves in territories controlled by ISIS and its resultant claim of "protection" for Muslim Women complement the myth of "real men".

With respect to how the relationship between manhood and womanhood has been established in political and societal terms, it is inevitable for us to make reference to feminist thinkers. For instance, Susan Brownmiller, one of the feminist authors discussing the connection between war and rape, attracts attention to the use of the female body to prove the social power of men during nationalist/ethnic wars. Brownmiller says that the female body, considered and defined to be a battlefield, is the area where the superiority of victorious men and the beating of defeated men are proven ${ }^{14}$. In other words, rape as a sexist form of violence is employed commonly during times of war as a symbol of the conquest of enemy territory. As analysed in

11 "Torture Archipelago: Arbitrary Arrests, Torture and Enforced Disappearance in Syria's Underground Prisons Since March 2011”, Human Rights Watch, 2012.

12 Willa Frej, "ISIS Female: Why women are drawn to join", MSNBC, 2014, October 25.

13 Carolyn Hoyle, Alexandra Bradford, and Ross Frenet, "Becoming Mulan: Female Western Migrants to ISIS", Institute for Strategic Dialogue, 2015.

14 Susan Brownmiller, Against Our Will: Men, Women and Rape. New York, Simon and Schuster, 1975, p. 309. 
her article concerning the use of rape as a strategy of war, Çiğdem Akgül argues that the encoding of the female body as the object of pleasure for the masculine eye masks the implication that female sexuality should be conquered underlying the discourse and presents this fact as an erotised passion. The men of a nation can have their manhood approved as long as they can desire this object of pleasure and be the conqueror of such desire $^{15}$. Thus, female bodies turn into the both abstract and concrete front for nations targeted to be defeated at the national scale ${ }^{16}$. At the same time, rape assumes a new meaning as the indicator of power and conquest among men fighting each other during war. By reason of this very perception, Cyntia Enloe defines rape as a tool of masculinised nationalism and points out to it as one of the indispensable tools of $\operatorname{war}^{17}$.

It is for this reason that ISIS places Western or non-Muslim men opposite the state of being "real men" as defined through rape. It attributes feminine characteristics to other states of manhood. Nevertheless, ISIS militants do not pretend to distinguish themselves from Western men only through the expression of "real men"; at the same time, they believe that the threat against being "real women" stems again from the Western culture or way of thinking, even though the same fact is not explained on the basis of this concept.

Indeed, the manifesto targets the definition of societal roles primarily of women by providing an apprehension concerning the mandatory lifestyles for women and the meaning of this lifestyle for the Islamic state rather than offering information on how women live under the current ISIS administration and therefore, feminist discussions which they think blurs this division of labour and define as being "Western" with strong language and from a critical standpoint. In fact, this also leads a significant portion of the manifesto to focus on criticisms of feminism as a concept defined as a "Western programme for women". In the face of the blurred division of labour among genders offered by feminism, a sharp distinction is made between the roles of women and men through the manifesto with references

15 Çiğdem Akgül, "Milliyetçi Söylemin Her Dem "Poine"si: Savaş Tecavüzleri." Alternatif Politika, 5/1, 2013, p. 95.

16 A.g.e., p.98.

17 Cynthia Enloe, Maneuvers: The International Politics of Militarizing Women Live. Berkeley, University of California, 2000, p. 189. 
to Islam. According to the Manifesto, the blurring of gender roles under Westernisation creates a distance between women and their motherhood or household roles, i.e. being "real women", and consequently between men and being "real men"18.

The basis of the gender policy employed by ISIS is represented by a certain restructuring of gender roles which has been intertwined by Westernisation in ISIS' words, the distinction of the roles of women and men from each other, the avoidance of any transitioning between such roles, and the shaping of the society on the grounds of such discrimination between sexes. In this respect, a complete dichotomy is presented between the state of womanhood equipped mostly with household roles and its sexuality restricted with child-rearing in the Islamic state and the belligerent state of manhood expressing its sexuality in pornographic terms through rape. This discrimination between sexes is defined as the basis of the prospective Islamic state and societal roles are designated through this discrimination. The difference between these roles is expressed as follows in the Manifesto:

Women have this Heavenly secret in sedentariness, stillness and stability, and men its opposite, movement and flux, that which is the nature of man, created in him. If roles are mixed and positions overlap, humanity is thrown into a state of flux and instability. The base of society is shaken, its foundations crumble and its walls collapse ${ }^{19}$.

As can be gathered from this sentence, the society is based upon a sharp segregation. It is forbidden for men and women to work or be educated together. The manifesto allows women to leave their homes only for the purposes of Jihad, studying the science of religion, or the need for female doctors and teachers and also puts forth the following clear line for women leaving their homes: "It is always preferable for a woman to remain hidden and veiled, to maintain society from behind this veil." ${ }^{20}$ The same text also states that the main duties of women are in the household and women cannot leave their homes for extended periods of time and this can only be allowed under exceptional conditions:

\footnotetext{
18 Winter, p.7.

19 Ibid., p.12.

20 Ibid., p.22.
} 
We have already clarified what the fundamental function for women is - it is in the house with her husband and children. However, there are other causes for which it is permissible for certain women to leave her home in order to serve society that we will recount below, God permitting (besides things that she customarily needs to do like traveling, on visits or hospitalized and so on). This is only in exceptional circumstances, not continually, as is the case with men ${ }^{21}$.

In addition to all of these matters, it is naturally forbidden for women to travel by themselves. This prohibition is clearly stated in the Manifesto with the following words: "Woman would not be allowed to travel out of the country unless they had a passport with a photo of their face in it." 22 However,

After the establishment of the caliphate, coverings and hijab things returned to the country and decency swept the country. Now, women are able to travel to their people in Raqqa without having to show their face to the eyes of even one inspector. Respect for their bodies has returned and has been taken from the eyes of onlookers, with their corrupted hearts. Causes of their humiliation are prevented, revealing dresses were confiscated from shops and scandalous photos were banned from walls and shelves. Muslims, with the permission of God, were cleansed ${ }^{23}$.

Actually, the apprehension defined in this paragraph for the Islamic State underlies the segregation between sexes. In other words, it is the difference in the roles imposed upon women and men in the foundation of a state. This understanding is a part of the definition of the relationship between woman and man in Islam on the basis of fitrat and the consequent interpretation of the same in the framework of 'complementary roles'. According to the principle of complementary roles between sexes in Islam, women and men have different roles in the society and any role in this system is not superior to the other. The gender policy employed by ISIS is based upon the tension that lies behind this division of roles between sexes. The present article will discuss this tension under a different heading through the roles allocated to women in the foundation of the "Shariah state".

\footnotetext{
$21 \quad$ Ibid., p. 22

22 Ibid., p. 28

23 Ibid., p.28.
} 


\section{Women as Stakeholders of the Apprehension of an Islamic State}

In the Manifesto, it is underlined that "Islam must be raised above all, women, men, sheikhs, children" 24 . This sentence used in the Manifesto is a good response to the frequently asked question as to "Why are women joining ISIS in greater numbers when compared to the other Islamic organisations including Al-Qaeda or Taliban?" In fact, this sentence claims that ISIS allocates different, but mutually complementary duties to women, men and children in its prospective Islamic state. According to this argument, women are not given only "passive roles" such as suicide bombing, but also "active roles" including founding the state. Implying that women may be involved actively in the founding of the state by not being absent, but, on the contrary, by being present, this understanding is the most important element that renders ISIS attractive for women. However, these "active roles" and "passive roles" are rather controversial. Indeed, the association of the "active role" of women in the foundation of the "Shariah state" with their fertility by ISIS can only be analysed and legitimised on the basis of patriarchy.

The Manifesto occasionally refers to the active roles assumed by women in politics in the initial years of Islam and underlines the fact that women are present as a founding element in the establishment and spread of Islam. Even though the roles imposed on women mostly concern household duties and motherhood, the statement that women can also take part in the fight at times when male forces remain inadequate provides for the possibility of women to fight at the frontlines of battle under compelling conditions. The recent claim that ISIS started to send female militants to the frontlines due to the difficulties it had encountered in recruitment as specified in a news article on Times journal ${ }^{25}$ should be considered in this context. The Manifesto explains that women can take part in the war in the context of Jihad along with its preconditions as follows:

Jihad (by appointment) - if the enemy is attacking her country and the men are not enough to protect it and the imams give a fatwa for it, as the blessed women of Iraq and Chechnya did, with great sadness, if the men are absent even they are present ${ }^{26}$.

$24 \quad$ Ibid., p. 23.

25 Bel Trew, "ISIS sends women into battle in Libya", The Times, February 29, 2016.

26 Winter, p.22. 
In fact, the female typology envisaged by ISIS is the woman of a society that always remains at war, i.e. holds its fundamental dynamics in Jihad. The mobilisation of women in the Jihadist process attains a new meaning for a society at war. Defined through women, the concept of family is interpreted not in affiliation with a specific nation or territory, but in the contrary context of Jihad and thus, constantly moving women will carry the tradition to all territories conquered by ISIS. The woman will assume her duties wherever Jihad is.

On the other hand, despite the fact that the principal duties of women in ISIS are mostly limited with the private space, there are duties that allow women to exist in the public sphere, as well. As an example, there are two all-female brigades under ISIS, namely al-Khansaa and Umm Al-Rayan. Specifically, al-Khansaa is known to be relatively active in the organisation. At first, the brigade was made up of female foreign fighters, and some of Arab nationality, with just a few Syrian women thrown in as well ${ }^{27}$.

Daily life in territories controlled by ISIS is almost entirely under the supervision of these all-female brigades that assume policing duties. In fact, it is these brigades that check whether the moral rules prescribed by ISIS are complied with, i.e. whether women are wearing full niqab veil or whether women go out of their homes escorted by men. Furthermore, women accompany men also at checkpoints. The duties assumed by women at such points are both to check women and to assist in the revealing of the identity of men concealing themselves under veil and niqap. In summary, while men fight at the frontlines, women play an important role in the process of the enforcement and supervision of Islamic moral rules under the Salafist interpretation of Islamic law in the country. Will McCants from the Brookings Institution define this situation as an effort to "engender fear and routinize obedience. ${ }^{228}$

Nevertheless, the following question comes to our minds: Does the Salafist interpretation designated equally by women and men? Naturally, women have no impact on such interpretation. Women rather concretise the roles

27 Zaid Al-Faras, "Isis: British schoolgirls set to join the sinister al-Khansa brigade in Syria", International Business Times, March 13, 2015.

28 Amanda Taub, "No, CNN, women are not joining ISIS because of 'kittens and Nutella", $C N N$, February 18, 2015. 
imposed by men upon themselves. In this situation, the question as to whether ISIS prefers women rather than men for such duties becomes more important than our previous question. Nimmi Gowrinathan, a UN researcher whose work focuses on women's participation in conflict and rebel movements, expresses the following comment in an interview. According to Gowrinathan, all insurgencies should receive support from both women and men. For such movements, female rebels bear a special meaning, because women can enter the circles of civilian women and enable women to be recruited for such movements. At the same time, the fact that the morality rules that all-female brigades enforce are based in religious doctrine and practice also reinforces the control of ISIS over conquered territories ${ }^{29}$.

On the other hand, we can analyse the meaning imposed by ISIS on women in domestic control also through the distinction between material/ spiritual realms offered by Partha Chatterjee for nationalist projects ${ }^{30}$. Indeed, women function as 'morality police' for ISIS as representatives of the spiritual realm as is the case in similar nationalisation/state-building projects under the distinction between material/spiritual realms in the backdrop of the dichotomy/juxtaposition between outside and inside. This, in turn, complements the meaning imposed upon women through their sex. On the contrary, men fulfil their duties concerning the material realm outside or at the frontlines by "defending the country". In other words, the appointment of women as police officers in charge of public order functions in concordance with the aforementioned principle of "complementariness". Different duties befall women and men in the foundation of the state and these duties are shaped on the basis of the meanings attributed to male and female sexes. As women are associated with morals/chastity, morality policing can be handed over to them. Nevertheless, there is no hierarchy established among the said duties even if we know it exists merely at the level of discourse.

In fact, regardless of how ISIS states that there is no hierarchy between the roles of women and men, this is not the case in effect. It appears that a

\footnotetext{
29 Taub, "No, CNN, women are not joining ISIS..."

30 Partha Chatterjee, Nationalist Thought and the Colonial World: A Derivate Discourse. Londra, Zed, 1986.
} 
different form of gender hierarchy is being generated through the separation of feminine and masculine public spaces in the division of roles between women and men on the basis of the principle of "complementariness" in the backdrop of fitrat in the process founding the "Shariah state". In this framework, ISIS allows the representation of women in public spaces it defines as "feminine"- e.g. teaching, medicine or policing -, while it assumes a reserved approach towards the representation of women in political decision-making processes - with mujahidism as an important part - defined as a masculine space. Despite this hierarchical representation, ISIS is able to impart a sense of being involved in the "Shariah state" as founding elements to women.

In short, we can state that this impact created by ISIS on women in the foundation process of the Islamic state is the most important reason underlying the joining of women in ISIS. Indeed, the report prepared by the Institute for Strategic Dialogue on the basis of its interviews with women joining ISIS mostly on Twitter confirms this observation. Published with the title Becoming Mulan, the report summarises one of the important reasons for women to join ISIS with the following statement: "In this way, ISIS's territorial gains and state-building project are crucial in attracting the women, who can see they have an important role to play in the new society" ${ }^{\prime 31}$. The report even quotes one of the female militants of ISIS as a respondent to support how widespread this belief is among women. As an example, Umm Ibrahim uses the following words in the interview: "The most important reasons the muhajireen came here was to re-establish the khilafah \& be part of bringing back the honor to this ummah"32.

It is also meaningful that the Institute for Strategic Dialogue held its interviews online, because the Internet is another area where women of ISIS can find a place for themselves. As a matter of fact, women of ISIS play an active role in online propaganda extended to secure new recruits for ISIS. Recommendations are offered to women who wish to join ISIS through Twitter pages and Tumblr accounts. Such recommendations and information include both practical information concerning the types of

\footnotetext{
31 Carolyn Hoyle, Alexandra Bradford, and Ross Frenet, "Becoming Mulan: Female Western Migrants to ISIS”. Institute for Strategic Dialogue, 2015.

32 Ibid., p.12.
} 
clothes women should bring with them before joining ISIS or what they will need in ISIS territories and basic information on Islam. Recommendations are offered even with respect to the possibility of joining ISIS directly by way of marriage with an ISIS militant as one of the most important roles imposed on women.

Indeed, serving the Islamic State by marring an ISIS militant as a "Wife of Jihad" and, more importantly, by giving birth to children for the Islamic State is the most prioritised role attributed by ISIS to women. The Manifesto published by ISIS clearly explains this duty imposed on women as follows: "We have already clarified what the fundamental function for women is it is in the house with her husband and children" ${ }^{33}$. In short, women are expected primarily to support their Jihadist men and thus, to contribute to the foundation of the Muslim community. Then, women are handed over the main burden of raising the children that will secure the continuity of the Muslim community.

Such duties, i.e. to act as a bridge that brings into existence future generations by connecting the past with the future and adds continuity to "oneness" 34 , are imposed upon women in all founding processes of states. Some do this through religion, some through ethnic identity. However, the common denominator in all of these processes is the linear association between nationalism or foundation of a state and manhood. As Joane Nagel stated, it is not surprising to see hegemonic culture and ideology of manhood going hand-in-hand with hegemonic culture and ideology of nationalism. Manhood and nationalism are articulated rather well into each other. Nagel also says that the modern form of Western manhood emerged at almost the same place and time as modern nationalism ${ }^{35}$.

Contemplating about and classifying these meanings imposed upon women in founding processes of states, Yuval-Davis and Anthias also

Winter, p.22.

34 Elleke Boehmer, "Stories of women and mothers: gender and nationalism in the early fiction of Flora Nwapa". In Susheila Nasta (Eds), Motherlands: Black Women's Writing from Africa, the Caribbean and South Asia., London: The Women's Press, 1991, p. $3-23$.

35 Joane Nagel, "Erkeklik ve Milliyetçilik: Ulusun İnşasında Toplumsal Cinsiyet ve Cinsellik" in Ayşe Gül Altınay (Eds.), Vatan, Millet, Kadınlar, İstanbul, İletişim Yayınları, 2004, p.75. 
mentioned five ways for women to take part in ethnic, national projects and founding processes of states. They list these meanings as follows: a) as the biological producers of members of ethnic communities, b) as the regenerators of the (normative) borders of ethnic and national groups (by displaying conventional feminine behaviour), c) by playing a central role of the ideological regeneration of the community and acting as transmitters of culture, d) as persons demonstrating ethnic/national differences, and e) by taking part in national economic, political and military conflicts ${ }^{36}$.

ISIS appears to define women also on the basis of these duties. In fact, ISIS not only defines the priority duty of women as taking care of their children and husband in the household in a manner consistent with point an above, but also foresees that they will be trained in this area. Then, ISIS imposes the duties concerning ideological regeneration, provision of normative borders and consequent transmission of the Islamic culture as emphasised in items b, c, and d through women fulfilling their duties in the household and assuming policing duties, as well. Finally, women of ISIS, tasked with the duty to fight for Jihad at the frontline in the absence of men, can take part in military conflicts as specified in item e. However, this last item is subject to the condition "if the men are absent" for ISIS. Therefore, women generally, or unless forced to act, assume duties that are limited with the "spiritual realm". Thus, women, being faced with such restrictions, tend occasionally to realise their nationalism through conventional roles imposed upon them again by nationalists - by supporting their husbands, raising their children (children of the nation) and acting as the symbols of honour for the nation ${ }^{37}$.

Nevertheless, the policy employed by ISIS for women also bears differences from conventional nationalist patriarchy as I stated before. While the Jihadist understanding of ISIS has emerged as a movement against those hegemonising globalisation, it actually and interestingly represents the redefinition of the global through Islamic references or in the context of Jihad in one sense. Jihadism responds to today's globalisation on the basis of the oldest apprehension of globalisation with its claim of an alternative

\footnotetext{
36 Nira Yuval Davis and Floya Anthias, Woman-Nation State. Londra, Macmillan, 1989., p.7-8.

37 Nagel, p.81.
} 
process of globalisation. Jihadism, in the sense defended by ISIS, argues for constant war and religious migration for the foundation of the country of Islam. Those emigrating for this ideal constitute the basis of ISIS. In other words, migrant male and female mujahids are the actual bearers of ISIS Jihadism. The diversity and differences between male and female mujahids of ISIS are greyed out or neutralised in Islam. It is clear that this interpretation differs from other Islamic states and other interpretations of Islam. However it is claimed that this interpretation is presented by ISIS as the most accurate interpretation of Islam.

According to the approach of ISIS to Jihad, women are defined in connection not with a specific country as is the case in nationalist patriarchy, but with statelessness. Becoming a 'bride of Jihad' or "wife of Jihad" assumes a meaning in the framework of this very definition. As a matter of fact the definitions of 'bride of Jihad' or "wife of Jihad" refer to migrant brides associated not with a territory, but with the Muslim community. According to this notion, migrating brides both serve Islam and fulfil the requirements of Islam. The parallel association established between migration or living as migrants upon breaking away from their territories of residence and becoming female mujahids is transformed into a cause-driven life upon marriage with a male mujahid. The research undertaken by the Institute for Strategic Dialogue actually shows that a significant portion of women joining ISIS have internalised the role of a "bride of Jihad" or "wife of Jihad" as prescribed also in the Manifesto published by ISIS. The following sentence offered by one of the female respondents providing input to the report is of importance for exemplifying such internalisation: "The best thing a man can do is Jihad, and the best thing for a women is to be a righteous wife and to raise righteous children." "38

In short, being a 'bride of Jihad' is considered by women of ISIS to be a part of a mentality that does not consider the territory of residence as home and moves towards statelessness. Here is an implication of women migrating in spiritual sense. In other words, this signifies the journey of women who feel oppressed by reason of their religion - in a similar fashion with the hegira of Mohammad. It appears that the feeling instigating this journey rests within the commonly asked question: "Why do Western women join ISIS?"

Hoyle, Bradford and Frenet, p.22. 


\section{A Controversial Question: Why Do Western Muslim Women Join ISIS?}

As the number of women in ISIS increase, the question "Why do Western Muslim women join ISIS?" comes to be asked more commonly and loudly despite its rather discriminative language. First of all, this question bears within itself a sense of confusion arising from the reversed direction of the migration flow which has been extending historically from the East to the West. In fact, this question also confirms the orientalist understanding in the background. Actually, the question that wonders about "Western" women joining ISIS regenerates a dichotomist language. The question essentially puts an emphasis on "Why does a woman prefer ISIS that is marked by 'backwardness', 'pressure', and 'barbarism' instead of 'developed', 'liberated' and 'civilised' West?". Incidentally, the question does not pose any inquiries concerning an Eastern woman joining ISIS. Women living in the East are assumed to have already internalised the said pressure. The question puts an insistent emphasis on Muslim women in the West. Through this means, a hierarchical language is being constructed in not only dichotomist, but also cultural terms between Muslim women living in the West and Muslim women living in the East.

As one of the figures searching for an answer to this rather common question, Dr. Erin Saltman, who researches processes of political radicalisation, justifies Western Muslim women joining ISIS through three headings. According to Saltman:

The first reason is an 'adventure narrative' that encourages young women to think of traveling to ISIS's territory as not just a religious obligation, but an exciting expedition to a "Muslim utopia". The second narrative was a humanitarian appeal, which presents ISIS's struggle as an effort that began as a fight against the oppressive Bashar al-Assad government and is now even more necessary because "global powers" are turning against Muslims. And finally, ISIS has successfully targeted western recruits via "romance" narratives. Some of those are directed at women, promising them that they will find a 'strong Muslim man, who is a true Muslim, who is fighting for this very heroic cause ${ }^{39}$

It is striking that Saltman does not express any criticism against the West while listing the reasons for Western Muslim women to join ISIS. The issue is discussed in a scope constrained between the promises of ISIS for women

39 Taub, "No, CNN, women are not joining ISIS...". 
and women's search for adventure. In fact, marrying "strong Muslim men" is also included in this search for adventure. First of all, we should move on with the discussion by underlining the fact that explaining the matter through such individual predispositions such as "adventure narrative" or to "find a strong Muslim man" or pathologicalising the matter also reinforces the orientalist outlook. In fact, Westerners continue to define ISIS recruits from Europe as a part of a search for adventure, whereas research shows that the feeling of pressure and denigration experienced by Muslims living in Europe had a significant impact upon the daily increasing number of recruits joining ISIS. As an example, the research undertaken by the Institute for Strategic Dialogue with Western women joining ISIS reveals that women join ISIS on certain grounds including the prohibition of burqa in such countries as France, discrimination they have encountered for being Muslim, and their inability to pray and worship Allah freely by reason of such discrimination. Women say that they have been isolated in Europe and wanted a safer environment. The report includes the following sentences with respect to the reasons specified for women for joining ISIS: "These women perceive themselves as migrating to an area where they can live 'honourably under the law of Shariah'"40. Many people who wish to have a more honourable life and cannot find this in Europe migrate from Europe to ISIS following the dream of Shariah. Therefore, there is a meaning here that goes beyond adventurism. This is associated more with Muslims who do not feel at home in their territory of residence. Hence, Muslims see their migration to territories controlled by ISIS as an Islamic requirement. An Islamic meaning is attributed to migration in order to associate it with hegira. In this context, the essential reasons for the reversed direction of migration from the East to the West appear to be the migrants' feeling of pressure by reason of religion and their ostracisation on grounds of cultural reasons.

In fact, all of these justifications can be summarised as follows: Increased Islamophobia in Europe advances the number of people in the West joining ISIS. However, while ISIS recruits militants from amongst people standing against Europe due to Islamophobia on one hand, it paradoxically contributes to the rise of Islamophobia through its treatment of European

40 Hoyle, Bradford and Frenet, p.22. 
prisoners and their terrorist actions the most recent example of which was in Paris. In the current situation, approximately 5000 militants of European origin are said to be active in ISIS ${ }^{41} .10$ to $15 \%$ of this number is estimated to be women. Even though Terrorism Research and Analysis Consortium (TRAC) state this ratio to be $15 \%{ }^{42}$, a newspaper article with an unknown source indicates it to be $10 \%{ }^{43}$.

Many people address Muslim women joining ISIS as the preference of "an oppressive administration", whereas the great majority of women see their escape from the alleged pressure and denigration they have encountered in Europe an important opening for liberation. In the face of the cultural hierarchy established in the West, the idea of ISIS keeping its promise and equalising people of different ethnic identities and colours under the Islamic administration becomes one of the important tools of propaganda for its efforts to recruit militants from the West. Militants from different countries coming together under ISIS builds the basis for ISIS' claim of reinterpreting globalisation in the context of Islam. ISIS expresses this understanding with the following words in the Manifesto:

There is no difference between Arabs and Persians, blacks or whites. All are under the rule of Islam. It is not possible to live in this Islamic way in any place ruled by tyrants, who implement nationalism over religion and patriotism over Shariah ${ }^{44}$.

In this sense, the sentence "You are of us and we of you" as given in the conclusion part of the Manifesto published by ISIS becomes important in that it satisfies the sense of belonging in the minds of many new recruits. ISIS approves the idea that Muslims have encountered discrimination in Europe by reason of their difference. Nevertheless, ISIS offers an alternative to those who don't feel that they belong to Europe and does not require any form of partnership other than the religion of Islam. This promise increases the number of Western recruits of ISIS. It appears that the concealed implication of "vulnerable women" in the question "Why

\footnotetext{
${ }^{41}$ “Avrupalı Kadın Üyeler için IŞiD’e yolculuk ‘tek yön’”, Euronews, May 2, 2015.

42 Atika Shubert and Bharati Naik, "From Food Recipes to AK-47s: Inside Online World of the Women of ISIS", CNN, September 10, 2014.

43 Willa Frej, "ISIS Female: Why women are drawn to join", MSNBC, 2014, October 25.

44 Winter, p.37.
} 
do Western women join ISIS?" becomes prominent as an orientalist image generated by the West in the context of discussions on women's reasons of joining ISIS. As a matter of fact, the reasons specified by women seem to point out to a stance of preferred resistance of women who have felt under pressure by reason of religion rather than a search for adventure among pathetic women. In clearer expressions, the reasons specified by women for joining ISIS intersect more with political realities rather than psychological notions. Muslims migrating from the West to the East believe that they can reverse the cultural hierarchy they feel to be in as Muslims in the West by founding a "Shariah state".

\section{Conclusion}

In conclusion, I addressed the policy employed by ISIS on women as a part of the organisation's apprehension of founding a state. This showed me that ISIS' policy on women is being shaped by patriarchal relationships in Islamic form. Women can become a part of the foundation process of the state to the same extent of their internalisation of these relationships. ISIS mostly specifies domestic roles specific to women as can be seen in the foundation processes of all states. Nevertheless, the roles imposed by ISIS on women inherently and always bear the tension of women as the carriers of the Islamic tradition along with the definition of the prospective state on a global plane. In clearer words, ISIS, going beyond the aim of establishing a nation-state, was forced to redefine its gender matrix in a global apprehension by reason of its Jihadist understanding or global claim.

In this respect, the definition of women through the concept of family in affiliation with the Muslim community as is the case in ISIS rather than with the country as is the case in nation-states is an effort to overcome this tension. In fact, the meaning of state does not differ for the masses whether it is in the Muslim community or in a nation; what differs is the nature of the political space where the state defines itself. According to this differentiation in the nature of the political space, the roles imposed on women and men vary, as well. The juxtaposition specified by ISIS between being 'real women' and 'real men' express the determining impact of the state on gender roles on one hand and underlines the political difference of the Islamic state from other forms of statehood. 
Moreover, the basis of the Islamic state envisaged by ISIS is represented by migrants. This is the underlying factor for the importance attached by ISIS to global propaganda. As a global movement, it is claimed that ISIS adds prominence to the nature of Islam as a religion that overcomes all differences, includes everyone and unifies all Muslims. ISIS responds to globalisation of Western origin with a Jihadist apprehension of globalisation in Islamic form. Women become involved in the fight for Islam as "brides of Jihad" or "wives of Jihad". "Brides of Jihad" or "wives of Jihad" go beyond their status as popular definitions and attain meaning as a tool for women to search for and migrate to a home for themselves. Nevertheless, the ability of women to become mujahids in territories where they live as migrants is subject to the condition of 'absence of men'. The actual inability of women, who are requested to become migrant brides, to become mujahids or the association of such ability with the inadequacy of men reveals the hierarchy which governs the aforementioned gender matrix. This hierarchy constitutes the basic axis of the gender policy employed by the state established by ISIS.

\section{Bibliography}

Akgül, Çiğdem, "Milliyetçi Söylemin Her Dem "Poine"si: Savaş Tecavüzleri." Alternatif Politika, 5/1, 2013, 91-113.

Arosoaie, Aido, "In the name of honour and freedom: the sacred as a justifying tool for ISIS' and Secular Violence", Culture and Religion, 18/3, 2017, 278-295.

Boehmer, Elleke, "Stories of women and mothers: gender and nationalism in the early fiction of Flora Nwapa". In Susheila Nasta (Eds), Motherlands: Black Women's Writing from Africa, the Caribbean and South Asia, London, The Women's Press, 1991, p. 3-23.

Brownmiller, Susan, Against Our Will: Men, Women and Rape. New York, Simon and Schuster, 1975.

Chatterjee, Partha, Nationalist Thought and the Colonial World: A Derivate Discourse. Londra, Zed, 1986.

Cook, David, "Women Fighting in Jihad?, Studies in Conflict \& Terrorism", 28/5, 2005, 375-384 
Enloe, Cynthia, Maneuvers: The International Politics of Militarizing Women Live. Berkeley, University of California, 2000.

Goldstein, Joshua S., War and Gender: How Gender Shapes the War System and Vice Versa, Cambridge, Cambridge University Press, 2001.

Nagel, Joane, "Erkeklik ve Milliyetçilik: Ulusun İnşasında Toplumsal Cinsiyet ve Cinsellik", in Ayșe Gül Altınay (Eds.), Vatan, Millet, Kadınlar, İstanbul, İletişim Yayınları, 2004.

Von Knop, Katharina, “The Female Jihad: Al Qaeda's Women”, Studies in Conflict \& Terrorism, 30/5, 2007, 397-414

Yuval Davis, Nira and Floya Anthias, Woman-Nation State. Londra: Macmillan, 1989.

\section{Internet sources}

“Avrupalı Kadın Üyeler için IŞi̇D’e yolculuk ‘tek yön”, Euronews, May 2, 2015, http://tr.euronews.com/2015/05/28/avrupali-kadin-uyeler-icinisid-e-yolculuk-tek-yon/, (Accessed: June 28, 2015).

Al-Faras, Zaid, "Isis: British schoolgirls set to join the sinister al-Khansa brigade in Syria", International Business Times, March 13, 2015, http:// www.ibtimes.co.uk/isis-british-schoolgirls-set-join-sinister-al-khansabrigade-syria-1491772, (Accessed: June 26, 2016).

Begum, Rothna and Samer Muscati, "Interview: These Yezidi Girls Escaped ISIS. Now What?", Human Rights Watch, April 15, 2015, https:// www.hrw.org/news/2015/04/15/interview-these-yezidi-girls-escaped-isisnow-, (Accessed: August 18, 2016).

Davis, Jessica, "Women and Terrorism in Radical Islam: Planners, Perpetrators, Patrons?", Conference Paper, March 2006, https://www.researchgate.net/publication/270959688_Women_and_Radical_Islam, (Accessed: September 12, 2017).

Frej, Willa, "ISIS Female: Why women are drawn to join", $M S N B C, 2014$, October 25, http://www.msnbc.com/ronan-farrow-daily/isis-female-whywomen-are-drawn-join, (Accessed: June 3, 2016). 
Hoyle, Carolyn, Alexandra Bradford, and Ross Frenet, "Becoming Mulan: Female Western Migrants to ISIS", Institute for Strategic Dialogue, 2015, http://www.strategicdialogue.org/ISDJ2969_Becoming_Mulan_01.15_ WEB.PDFBecoming Mulan. (Accessed: September 12, 2016).

Kıvanç, Ümit, “Iş̧iD-DAİş'e Batı'dan Niye Katılıyorlar?” Radikal Gazetesi, 2015, October 11, Radikal Gazetesi, http://www.radikal.com. $\operatorname{tr} /$ yazarlar/umit-kivanc/isid-daise-batidan-niye-katiliyorlar-1475316/, (Accessed: March 4, 2017).

"Roughly 3000 Women and Girls are Sold on ISIS Sex Slave market Using Telegram, Whatsapp", Ny Daily News, July 6, 2016, http://www.nydailynews.com/news/world/roughly-3-000-women-girls-sold-isis-sex-slavemarket-article-1.2700156, (Accessed: June 24, 2016).

Saul, Heather, "Life as Woman Under ISIS Document Reveals for the First Time What Group Really Expects from Female Recruits Living in Syria and Iraq", Independent, 2015, July 23, http://www.independent.co.uk/ news/world/middle-east/life-as-a-woman-under-isis-document-revealsfor-the-first-time-what-group-really-expects-from-female-10025143.html, (Accessed: March 3, 2017).

Shubert, Atika and Bharati Naik, "From Food Recipes to AK-47s: Inside Online World of the Women of ISIS", CNN, September 10, 2014, http:// edition.cnn.com/2014/09/10/world/meast/iraq-syria-isis-women, (Accessed: July 3, 2016).

"The Revival of Slavery: Before the Hour", Dabiq, 2015, http:/www. danielpipes.org/rr/2014-10-dabiq.228.pdf, (Accessed: March 3, 2017).

"Torture Archipelago: Arbitrary Arrests, Torture and Enforced Disappearance in Syria's Underground Prisons Since March 2011", Human Rights Watch, 2012, http://www.hrw.org/sites/default/files/reports/ syria0712webwcover.pdf, (Accessed: July 13, 2016).

Trew, Bel, "ISIS sends women into battle in Libya", The Times, February 29, 2016, https://www.thetimes.co.uk/article/isis-sends-women-intobattle-in-libya-rjmhqc7k7, (Accessed: March 2, 2016).

Wilson, Lydia, "Women in the Islamic State", Conference Paper, September 2016, https://www.researchgate.net/publication/305686811_WOMEN_IN_THE_ISLAMIC_STATE, (Accessed: March 5, 2017). 
Winter, Charlie, "Women of the Islamic State: A Manifesto on Women by the Al-Khanssaa Brigade", Quilliam, February 2015, https://therinjfoundation.files.wordpress.com/2015/01/women-of-the-islamic-state3.pdf, (Accessed: February 21, 2017). 